\title{
O NOVO DICIONARIO DA REAL ACADEMIA GALEGA
}

\author{
Manuel González González \\ Real Academia Galega / Universidade de Santiago de Compostela
}

\section{INTRODUCIÓN}

Cando en 1905 a Asociación Iniciadora y Protectora de la Academia Gallega de La Habana impulsou a creación da RAG, encomendoulle como unha das principais tarefas a de realizar o dicionario da lingua galega. Neste momento xa se coñecían algúns dicionarios do galego, todos eles de carácter bilingüe, que no fondo tiñan sempre como punto de referencia o castelán. Pero nin o dicionario de F. J. Rodríguez (1863), nin o de Cuveiro (1876), nin o de Valladares (1884) podían considerarse obras de referencia nin sequera cos criterios lexicográficos pouco esixentes da época, aínda que hai que recoñecer que a obra de Valladares supuxo un adianto considerable con respecto ás dúas anteriores. En realidade, no único aspecto en que os lexicógrafos do XIX superaron o labor realizado no XVIII polos seus antecesores Sarmiento e Sobreira, foi en darlles ás súas obras un formato máis próximo ao que hoxe consideramos un dicionario. Coa vontade de dar un paso cualitativo dentro da lexicografía galega comezaron os traballos do Diccionario da RAG cun fervor realmente admirable. Para a súa realización pediuse a colaboración de todos os académicos da institución e daquelas persoas que naquel momento estaban en posesión dalgunha recolla léxica galega ou con ganas de levala a cabo. Desde aquela houbo diversas contribucións importantes no campo da lexicografía galega, que non é este o momento de examinar nin de valorar. Foi no 1990 cando se deron os pasos máis firmes no aspecto metodolóxico na lexicografía monolingüe, coa publicación por parte do Instituto da Lingua Galega e a Real Academia Galega do Diccionario da lingua galega (ILG/RAG 1990), Aínda que contaba só con 12.000 entradas, supuxo un avance decisivo en aspectos metodolóxicos tan importantes como: 
(a) o coidado na redacción das definicións, que se realizan facendo uso unicamente das palabras que figuran como entradas no propio dicionario, e que evitan en todo momento a circularidade, tan frecuente nalgúns traballos lexicográficos;

(b) a precisión nas indicacións categoriais, particularmente nos verbos, que se traduce non só nas anotacións de tipo gramatical, senón tamén na propia organización das definicións;

(c) a incorporación de exemplos a cada unha das acepcións recollidas;

(d) a indicación para cada unha das acepcións dos sinónimos, antónimos e palabras próximas semanticamente.

Probablemente a obra máis fiable e máis acabada de toda a historia da lexicografía galega, pese ao número relativamente reducido de entradas, xa que unicamente conta con 25.000 lemas, sexa o DRAG (1997). É un dicionario de uso, pero coa restrición do seu carácter normativo, o que explica que un número considerable de palabras empregadas habitualmente no galego non aparezan recollidas, por seren voces espurias innecesarias ou por teren un marcado carácter dialectal. Aínda así, pola alta frecuencia de uso que presentan, dáselles cabida a algunhas destas palabras non recomendables, pero van sempre precedidas dun asterisco, e desde elas remítese para a forma galega considerada máis correcta.

O carácter máis novidoso desta obra é a sistematicidade e modernidade da técnica lexicográfica na microestrutura das entradas. Cada artigo presenta unha información estruturada de tipo fonético (cando é pertinente), gramatical, léxico, nivel de lingua, ámbito de especialidade, etc. A incorporación do principio lexicográfico de que toda definición debe poder substituír o termo definido nun contexto dado levou a preocuparse de que a perífrase da definición teña unha forma tal que poida desempeñar a función sintáctica propia da palabra definida, así como á separación entre o núcleo e o contorno da definición. É esta a primeira obra de lexicografía galega en que se segue este principio de maneira sistemática. Cada unha das acepcións leva un ou varios exemplos de uso que, amais de proporcionar ao usuario un modelo de utilización concreta da palabra dentro dun enunciado, actúa tamén de elemento de contraste para someter a proba a corrección e adecuación da definición. Na selección de exemplos tívose especial coidado por evitar o clasismo, o sexismo e, en xeral, a transmisión de ideas non acordes cos principios de igualdade de todos os seres humanos, de convivencia democrática e de respecto pola natureza. O mesmo ca no dicionario de 1990, tamén neste se indica para cada acepción os sinónimos, antónimos e outros termos que presentan 
unha estreita afinidade semántica. Cada artigo cérrase coas locucións, frases feitas e modismos nos que aparece o lema da entrada como palabra base ${ }^{1}$. Neste momento a Real Academia Galega está traballando nun novo dicionario das mesmas características técnicas ca o anterior, pero de 50.000 entradas, e del é do que imos falar.

\section{O DRAG, DICIONARIO NORMATIVO}

Vimos xa que o primeiro encargo que se lle fixo á RAG foi a elaboración dun dicionario da lingua galega, que recolla a riqueza léxica da nosa lingua, aínda en boa parte non recompilada, pero tamén que sirva de orientación para a súa escrita. ODRAG debe ser, pois, un dicionario de lingua, no que se atope aquela parte do léxico que é común á maior parte dos falantes e que estes utilizan nas súas interrelacións habituais, pero tamén un dicionario normativo ao que o usuario poida acudir para saber se a forma, o contido, ou as características gramaticais dunha determinada voz pertencen ao que se considera bo galego ou non. Debe ser, pois, un dicionario que oriente sobre o uso correcto:

(a) na forma das palabras, tanto na súa vertente escrita (se unha palabra se escribe con $b$ ou $v$, con $h$ ou sen $h$, etc.), como na súa vertente oral (se unha palabra se pronuncia con $e$ aberto ou pechado, con $s$ ou con $x$, etc.). Por iso debe advertir, nos casos en que un grafema poida representar máis dun fonema, a cal dos fonemas representa en cada caso concreto;

(b) nos significados;

(c) nas características morfosintácticas;

(d) no rexistro.

\section{AS FONTES PARA A ELABORACIÓN DO DRAG}

Os primeiros dicionarios da lingua galega foron realizados por afeccionados que pacientemente ían apuntando as palabras que escoitaban no seu lugar de nacemento, no lugar onde vivían ou nos lugares que visitaban. Nalgúns casos incorporaron algúns datos extraídos de textos escritos, literarios ou non, pero en todo caso non se baseaban nun conxunto de textos orais ou escritos que puidesen ser considerados como represen-

1. Para a análise máis polo miúdo das características desta obra pode verse González González (1996). 
tativos do conxunto da realidade lingüística dun determinado momento. Hoxe non se entende a elaboración dun dicionario de lingua sen un corpus que lle sirva de base.

A información do $D R A G$ está elaborada a partir de tres tipos principais de fontes:

(a) Obras lexicográficas anteriores (dicionarios, vocabularios, léxicos...);

(b) Corpus representativo da lingua escrita do galego moderno;

(c) Corpus representativo da lingua oral do galego actual.

\subsection{Os dicionarios e obras lexicográficas anteriores}

Pódese dicir que dalgunha maneira o DRAG é debedor de todas cantas obras lexicográficas foron realizadas con anterioridade á súa elaboración, porque todas elas foron tidas en conta, mesmo en moitos casos para rexeitar a súa información. Pero permítaseme sinalar algunhas das obras históricas máis significativas: toda a información léxica contida nas obras de Sarmiento $(1970,1973,1975,1986,1999)$ e de Sobreira (cfr. Pensado 1974), a Traducción de algunas voces, frases y locuciones gallegas, especialmente de agricultura al castellano atribuída a Reguera y Pardiñas (18401858), os dicionarios e vocabularios de F. J. Rodríguez (1863), Juan Manuel Pintos (1865), Juan Cuveiro Piñol (1876), Marcial Valladares (1884) (cos suplementos de 1896 a 1902), Francisco Porto Rey (1900-1908), Leiras Pulpeiro (ca. 1906) (cfr. Pérez Pascual / Tato García 1986), Payzal (cfr. Ferreiro 1994), DRAG (1913-1928), X. F. Filgueira Valverde et alii (1926), Leandro Carré Alvarellos (1928-1931), Acevedo y Huelves / Fernández y Fernández (1932), Aníbal Otero (1949-1977, 1967, 1977), Eladio Rodríguez (1958-1961) (co apéndice), Franco Grande (1968), Ríos Panisse (1977, 1983), Elixio Rivas (1978, 1988, 1996, 1997a, 1997b, 1997c, 1998a, 1998b, 2003), Constantino García González (1974, 1985), Francisco Romero Lema (2000), etc.

Hoxe, a maioría destas obras están recollidas no Diccionario de diccionarios (Santamarina 2003b), que nos últimos anos nos facilitou moito o traballo, xa que permite unha consulta moito máis cómoda da información sobre unha palabra nos distintos dicionarios, facilita o seguimento histórico das voces nas obras lexicográficas (copias, malas lecturas, malas interpretacións...), e supón un aforro de tempo importantísimo para a consulta das fontes lexicográficas que incorpora. 


\subsection{O Tesouro Lexicográfico da Lingua Galega}

O Tesouro Lexicográfico da Lingua Galega é un amplo conxunto de fichas léxicas con voces recollidas especialmente da lingua oral, posto en marcha a finais dos anos sesenta por Constantino García no Departamento de Filoloxía Románica da Universidade de Santiago, e que despois, cando se creou o Instituto da Lingua Galega, pasou a esta institución. Este ficheiro contén voces procedentes de:

(a) teses de doutoramento e memorias de licenciatura realizadas sobre falas de distintos puntos de Galicia ou ben sobre elementos da cultura material ou espiritual de Galicia;

(b) enquisas realizadas por alumnos das materias que impartía o Departamento de Filoloxía Románica e por outros colaboradores que achegaban información máis ou menos ocasional;

(c) gravacións de textos orais.

Como cabería esperar pola formación dos seus recolectores, esta información non ofrece toda o mesmo nivel de fiabilidade. Non teñen o mesmo valor os datos proporcionados por un doutor, especialista en lingüistica, que os achegados por un alumno ou por un afeccionado que, aínda poñendo toda a súa mellor vontade, non sempre posúen a formación académica suficiente para transmitir con precisión aquilo que escoitaron ou coidaron escoitar. Esta é a razón que levou a clasificar a información do ficheiro en tres tipos de fichas, de distintas cores, segundo o nivel de confianza que ofrecesen:

(a) a información procedente de teses ou memorias de licenciatura ou de traballos contrastados cientificamente recóllese en fichas de cor branca;

(b) a procedente de enquisas de alumnos ou colaboradores, en fichas de cor amarela;

(c) a información procedente da transcrición de gravacións de textos orais, en fichas de cor azul.

O soporte desta información en fichas de papel limita o seu aproveitamento. Sería moi difícil, por exemplo, coñecer todos os sinónimos que aparecen para bidueiro, porque esixiría percorrer todas as fichas contidas en cada un dos centos de caixóns que integran o ficheiro. Por iso se intentou a informatización deste ficheiro nunha base de datos con nove campos: 

(a) forma dialectal
(b) forma normativa
(c) equivalencia en castelán
(d) categoría gramatical
(e) campo nocional
(f) exemplo
(g) lugar de recollida
(h) notas
(i) fonte

Para o campo nocional, deseñouse un modelo no que o universo se estrutura en dez campos; cada un destes subdívidese noutros dez, e cada un destes de novo noutros dez, etc.:

1. Ceo e atmosfera

2. Terra

3. Plantas

3.1. A vida vexetal en xeral

3.2. Árbores

3.2.1. Xeneralidades

3.2.2. Árbores madeirables

3.2.3. Árbores froiteiras

etc.

\subsection{O Tesouro Informatizado da Lingua Galega (TILG)}

É unha base de datos do léxico contido nun corpus do galego moderno. Trátase dun proxecto dirixido por Antón Santamarina, no Instituto da Lingua Galega, cunha finalidade principalmente lexicográfica. Contén ao redor de 11 millóns de rexistros, e abrangue o ámbito temporal comprendido entre o ano 1671 e a actualidade.

O corpus está integrado por:

- textos literarios

- textos xornalísticos

- textos de carácter técnico e científico

- textos de literatura oral

- textos orais sen carácter literario 
Coa finalidade de facilitar o seu tratamento, os textos foron sometidos a un proceso de normalización e uniformización ortográfica. Por exemplo:

(a) Reducíronse a $n h$ as diversas formas para representar a consoante nasal velar en posición intervocálica: unha, un-a, un-ha, umha > unha;

(b) Regularizouse o uso de $b$ e $v$, segundo os criterios ortográficos do galego actual: avó, abó > avó;

(c) Regularizouse o emprego de $h$, segundo a ortografía vixente na actualidade: hoso, óso > óso:

(d) Modificouse o uso do acento gráfico seguindo os criterios de acentuación das normas ortográficas actuais: cantéi, cantei > cantei; pèrtega, pértega > pértega.

O proceso de regularización do texto facilita o traballo de lematización, pero ten dous inconvenientes de certa importancia: non permite facer un seguimento da evolución da ortografía a través dos textos que contén, e esixe ter que acudir sistematicamente ás fontes para comprobar a ortografía cando se quere facer unha cita textual.

Esta base de datos ofrécenos para calquera voz as concordancias, o seu lema e a categoría gramatical á que pertence.

\subsection{Corpus de Referencia do Galego Actual (CORGA)}

O Corpus de Referencia do Galego Actual foi elaborado no Centro Ramón Piñéiro para a Investigación en Humanidades, e está dirixido por Guillermo Rojo.

O CORGA contén unha colección de documentos en formato electrónico, na que están representados os diferentes tipos de textos da lingua galega actual. Abrangue o ámbito cronolóxico comprendido entre o ano 1975 e a actualidade. Trátase, pois, dun corpus referido exclusivamente ao galego actual ou recente.

É un corpus que pretende ser equilibrado, con representación proporcional de textos de distintos xéneros, de distintas áreas temáticas e de distintos anos. As grandes áreas temáticas en que se clasifican os textos son:

- Economía e política

- Cultura e artes

- Ciencias sociais

- Ciencia e tecnoloxía 
- Ficción

- Outros

Na constitución temática do corpus tivéronse en conta non só as áreas temáticas, senón tamén as subáreas. Por exemplo, na área temática “Economía e política”, están representadas as subáreas de:

- Política

- Desenvolvemento e infraestruturas

- Emprego, traballo, industria

- Sector servizos

- Explotación primaria

- Economía, facenda, bolsa

- Ordenación sanitaria

- Xustiza, lexislación, dereito

- Asuntos sociais

- Ordenación académica

As buscas e concordancias pódense realizar sobre o conxunto do corpus, ou ben restrinxilas a unha ou varias áreas temáticas. O usuario pode seleccionar tamén o período cronolóxico que sexa do seu interese:

$-1975-1979$

$-1980-1984$

$-1985-1989$

- 1990-1994

- 1995-1999

- 2000-2004

Deste corpus existen dúas versións en liña. A primeira contén 17.5 millóns de formas, e está dispoñible no enderezo http://corpus.cirp.es/corga. A segunda, sobre a que aínda se está a traballar, contén neste momento 13.3 millóns de formas, e está dispoñible no enderezo http://corpus.cirp. es/corgaxml ${ }^{2}$.

A segunda versión en .xml creouse para posibilitar un sistema de recuperación de información máis flexible e efectivo, e obrigou a unha codificación e deseño dunha estrutura formal que dea conta da disposición 
interna característica de cada un dos grandes tipos de textos (xornalísticos, ensaio, novela...).

Estase ultimando unha ferramenta de análise gramatical automática e de desambiguación, que permitirá a lematización automática, a actualización da base cun custo económico baixo, e buscas secuenciais por categorías (por exemplo, verbo tirar + preposición).

\subsection{O Atlas Lingüístico Galego (ALGa)}

O Atlas Lingüístico Galego proporciona valiosísima información sobre a realidade léxica do galego actual, co valor engadido de que permite a súa localización xeográfica e examinar a extensión no territorio dunha voz cun significado determinado.

Neste momento lévanse publicados 5 volumes desta obra, pero para o DRAG fixéronse tamén con frecuencia consultas sobre os cadernos para documentar determinados significados de voces populares.

\subsection{O Arquivo do Galego Oral}

Outra fonte de procedencia oral con certo interese para o DRAG é o Arquivo do Galego Oral, proxecto dirixido por Francisco Fernández Rei, no ILG, e que contén gravacións de máis de 2.000 puntos de todo o territorio de fala galega. Neste momento aínda non está transcrito todo o material contido nas gravacións.

Aínda que a súa finalidade non é puramente lexicográfica, as súas concordancias son utilísimas para coñecer o uso das palabras, para examinar os contextos de utilización e para ver o seu valor real.

\subsection{O Tesouro Fraseolóxico Galego (TFG)}

Nos dicionarios actuais, cada vez se lle ofrece maior importancia á fraseoloxía, e para atender este aspecto resultou de axuda inestimable o proxecto, dirixido por Xesús Ferro Ruibal no Centro Ramón Piñeiro, que leva por título Tesouro Fraseolóxico Galego.

O TFG sobrepasa neste momento as trescentas mil entradas, con datos que van desde mediados do século XVIII ata hoxe, pero con predominio dos correspondentes aos últimos oitenta anos.

Por seren os fraseoloxismos unidades cunha estrutura máis ou menos fixada, cun significado que, na maior parte dos casos, non é a suma dos significados das palabras que as integran, enténdese facilmente que cada 
vez se lles dea unha maior importancia nos dicionarios modernos. Tense dito moitas veces que non se coñece en profundidade unha lingua ata que non se coñecen ben os seus fraseoloxismos. Pero, ademais, así como no léxico dunha lingua se reflicte dalgunha maneira a historia e as experiencias dos pobos, a fraseoloxía revélanos por veces dun xeito moi transparente a maneira particular de ver a realidade de cada sociedade ou de cada cultura.

\section{A MACROESTRUTURA DO DRAG}

\subsection{As entradas}

O Dicionario da Real Academia Galega contén ao redor de cincuenta mil artigos lexicográficos, e as súas entradas están baseadas no Vocabulario ortográfico da lingua galega (VOLG), con algúns engadidos:

(a) Considerouse conveniente completar algunha familia de palabras que no VOLG aparecía unicamente cos seus membros máis relevantes.

(b) Introducíronse algunhas voces non incluídas no VOLG, xeralmente pertencentes a linguas de especialidade, pero que presentan certo uso.

(c) Completouse algunha serie de palabras que constitúen un conxunto completo claramente delimitado, e que por algunha razón quedou incompleta no VOLG.

O VOLG é unha proposta de vocabulario normalizado da lingua galega. A primeira edición provisoria saíu no ano 1990, en edición non venal, e a primeira edición oficial é do ano 2004. Actualmente pódese consultar na páxina da RAG a versión en liña deste vocabulario (www.realacademiagalega.org). Esta versión en liña presenta xa algunhas correccións e novidades con respecto á editada en papel. A realización desta proposta de vocabulario normalizado da lingua galega esixiu realizar unha selección de formas dialectais dentro do propio galego, levar a cabo unha depuración de castelanismos e de voces espurias innecesarias, facer unha proposta de ortografía, acentuación e morfoloxía correctas, e, en certa medida, afrontar tamén o problema de actualización e modernización do léxico.

Foi necesario, en primeiro lugar, facer unha selección de formas dialectais. Por poñer un exemplo que sexa claramente comprensible, para designar a árbore betulla, de entre un gran número de formas existentes (bidueiro, bedueiro, bidoeiro, bidoeira, budueira, abedoeira, abedueiro..., bedugo, bedulo, 
dulo, bídalo, bido, budio...) foi necesario escoller unha delas, neste caso bidueiro, para a norma estándar. Evidentemente, as escollas non poden ser feitas de xeito arbitrario, senón seguindo unha serie de criterios da maneira máis coherente posible. Os principais criterios seguidos no VOLG para a selección dialectal foron: a autenticidade da forma, a extensión xeográfica, a tradición literaria e a coherencia interna dentro da mesma familia.

O VOLG significou un avance extraordinario tamén na depuración de castelanismos e voces espurias innecesarias. $O$ préstamo lingüístico pode ser necesario en certos casos, cando designa unha realidade nova, pero debe evitarse que unha voz foránea retire da circulación outra galega que designe o mesmo concepto. Por iso se excluíron castelanismos moi introducidos, como por exemplo abonar, para restituír no seu lugar a forma patrimonial galega aboar; ou lusismos con certa implantación literaria, como aceitona, anceio ou saudade, para darlles prioridade ás voces propiamente galegas oliva, ansia ou devezo, e soidade.

O VOLG é unha proposta de ortografía correcta para a lingua galega. Na tradición escrita do galego moderno existen tendencias gráficas alleas á historia e á evolución da propia lingua. Son frecuentes grafías debedoras do castelán como *acibro, ${ }^{*}$ trebo, ${ }^{*} b a r r e r$, e hai grafías que só se explican baixo a influencia do portugués, como por exemplo * povo. Todas elas foron restituídas á forma ortográfica máis acorde cos criterios gráficos do galego: acivro, trevo, varrer, pobo.

A presión do castelán, e a penetración dun gran número de cultismos a través desta lingua, introduciu nos falantes galegos un alto número de acentuacións antietimolóxicas, que foi necesario corrixir na proposta normativa do léxico galego: fronte ás realizacións populares, introducidas a través do castelán, do tipo *ósmose, ${ }^{*}$ diócese, ${ }^{*}$ atmósfera, ${ }^{*}$ isobara, ${ }^{*}$ fotolise, "monolito..., propuxéronse as formas con acentuación máis etimolóxica osmose, diocese, atmosfera, isóbara, fotólise, monólito...

No VOLG tamén se fai unha proposta de morfoloxía correcta para a lingua galega: indícase o xénero correcto de cada substantivo (condénanse, por exemplo, usos como ${ }^{*}$ fraude, ${ }^{*}$ sindrome, fronte ás formas recomendadas a fraude, a síndrome), indícase o réxime de cada verbo, do que aparecen usos incorrectos debidos á interferencia co castelán (quecer (i) / quentar, adormecer (i) / adormentar, amarelecer (i) / amarelar).

Naqueles casos en que a formación do feminino ou do plural pode ser problemática, tamén se informa sobre este particular: afgán /f: afgá, pero cachán / f: cachana.

Outra función que tivo que cumprir o VOLG é a de actualización e modernización do léxico. O galego, debido ás especiais circunstancias histó- 
ricas que lle tocou sufrir, quedando circunscrito practicamente ao mundo agrícola e mariñeiro, desenvolveu un léxico rico para estes ámbitos, pero non se adaptou lexicamente a aquelas áreas nas que non era lingua de uso habitual (ciencia, administración, tecnoloxía...). Foi necesario, xa que logo, facer un esforzo para capacitar a lingua para as novas necesidades da sociedade actual, actualizando o seu léxico mediante distintos procedementos:

(a) Préstamo doutra lingua: xenismos (khmer), préstamos integrados (bisté, chalé, estándar);

(b) Cultismo latino ou grego: elipse, metátese...;

(c) Revitalización de arcaísmos: ousia, doazón, xaxuar, taxa...;

(d) Calco: autoestrada, altofalante...;

(e) Creación autóctona: mostraxe, lastro, beirarrúa, rede de sumidoiros...

\subsection{Algúns problemas referidos á macroestrutura}

Os autores de calquera dicionario moderno, á hora de decidiren a súa macroestrutura, teñen que tomar unha serie de decisións sobre problemas como: qué unidades terminolóxicas introducir, o tratamento dos homónimos, o tratamento de formas morfoloxicamente irregulares, qué facer coas lexías compostas e as frases feitas, qué papel se lles vai dar ás palabras non normativas, etc. Vexamos cal é o comportamento do DRAG con respecto a estas cuestións.

\subsubsection{O tratamento da terminoloxía}

Dilucidar qué unidades terminolóxicas deben ser introducidas nun dicionario xeral dunha lingua é un asunto longamente discutido. Nunca coma hoxe houbo tanta osmose entre as linguas de especialidade e a lingua común, no que se refire ao léxico. Isto é unha consecuencia lóxica do aumento do nivel cultural das sociedades modernas e da democratización do coñecemento. Un termo coma o rato dun ordenador, que hai ben poucos anos pertencía á lingua de especialidade da informática, hoxe debe considerarse unha voz xa integrada na lingua habitual de calquera persoa. De maneira xeral, podemos dicir que nun dicionario de lingua deben ter cabida os termos, en canto unidades léxicas, que non pertenzan a un nivel altamente especializado.

Un problema especial preséntao o tratamento dos símbolos. Dentro das unidades de coñecemento especializado, temos unidades lin- 
güísticas (léxicas, fraseolóxicas e oracionais), pero encontramos tamén unidades non lingüísticas (símbolos, fórmulas, nomenclaturas, iconografía). Debemos preguntarnos, pois, qué facemos, por exemplo, cos símbolos químicos. Deben ter cabida no dicionario os símbolos $\mathrm{H}$ (que representa o hidróxeno) ou O (que representa o osíxeno)? En realidade, os símbolos son unidades non lingüísticas de coñecemento especializado, semellantes en certo modo ás iconas; pensemos por exemplo no que simboliza

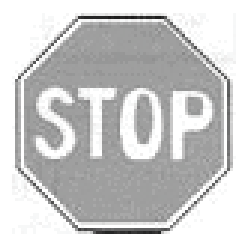

$\mathrm{E}$, se lle damos cabida no dicionario a $\mathrm{H}$ ou a $\mathrm{O}$, debemos preguntarnos tamén por qué non facemos o mesmo con, por exemplo, $\mathrm{H}_{2} \mathrm{SO}_{4}$, que representa o ácido sulfúrico.

O tratamento que os dicionarios lles dispensan aos símbolos químicos difire radicalmente duns a outros. Hai dicionarios que os acollen e outros que se negan a darlles cabida (por exemplo, un tan coñecido como - Vocabolario della lingua italiana de Zingarelli). No DRAG optamos por darlles cabida a algúns por razóns de tipo práctico, pero sen estarmos convencidos da súa inclusión desde un punto de vista teórico.

\subsubsection{Tratamento dos homónimos. O problema da homonimia e da po-} lisemia

En realidade, desde o punto de vista sincrónico, un signo lingüístico é unha unidade dotada dunha expresión fónica e un contido semántico. Deste xeito, cada acepción dunha voz (ou mellor, cada invariante significativa) constituiría un signo lingüístico distinto, e poderíase pensar nunha entrada distinta para cada relación significante-significado. Pero esta é unha práctica pouco seguida ata agora na lexicografía, por unha razón moi simple, porque todos temos conciencia de que diversos significados poden ser asignados a un mesmo significante, e de que entre estes significados existe moitas veces unha relación especial (de proximidade semántica, de derivación xenética entre un e outro, etc.).

Nas obras lexicográficas habitualmente véñense agrupando baixo un mesmo lema os casos de polisemia, e sepáranse en lemas distintos os casos de homonimia. O problema está daquela en distinguir entre homonimia e polisemia. As diferencias entre homonimia e polisemia non sempre 
están claras, e non todos os lingüistas seguen os mesmos criterios para diferenciar unha doutra. Os criterios máis frecuentes de distinción son:

(a) O etimolóxico: considéranse casos de polisemia aqueles en que os distintos significados que se asignan a un único significante derivan dun mesmo étimo; e considéranse casos de homonimia aqueles en que os distintos significados que se corresponden cun mesmo significante derivan de étimos distintos.

(b) Outras veces acódese á conciencia dos falantes, para dirimir se estamos ante un caso de homonimia ou de polisemia.

(c) Tamén con frecuencia se botou man de criterios semánticos, considerando, por exemplo, casos de polisemia aquelas acepcións que pertencen a un mesmo campo semántico, e casos de homonimia os demais.

No DRAG séguese un criterio historicista, baseado na etimoloxía:

\footnotetext{
sacha $^{1}$ s.f. Ferramenta agrícola utilizada para sachar, que varía de forma e de tamaño segundo os lugares. Colleu a sacha e foi cara á leira. SIN. sacho.

sacha $^{2}$ s.f. 1 . Acción de sachar. Xa logo empezaban coa sacha do millo. A sacha é un labor pesado. SIN. cava $^{1}$, sachada, sachadura. 2. Época en que se realiza este labor. Creo que ocorreu pola sacha das patacas. SIN. sachega.
}

No caso de sacha ${ }^{1}$ estamos ante unha formación a partir de sacho, que procede do lat. SARCULUM; en cambio, no caso de sacha ${ }^{2}$ encontrámonos diante dun substantivo deverbal, formado a partir do verbo sachar.

\subsubsection{Tratamento de formas morfoloxicamente irregulares}

Aínda que como cabeza de artigo lexicográfico figuran unicamente os lemas (as formas do masculino singular no caso dos substantivos e adxectivos, e o infinitivo no caso dos verbos), hai veces en que se incorporan como entradas tamén outras formas que son morfoloxicamente irregulares, co fin de facilitar o uso do dicionario a persoas que non teñen un coñecemento profundo da lingua. Nestes casos non se ofrece a información lexicográfica da voz, e remítese para o seu lema correspondente:

poetisa s.f. V. poeta.

poeta s.m. (f. poetisa) Persoa que escribe poesía. OBS. Tende a utilizarse a forma poeta como feminina, en lugar de poetisa. Curros Enríquez é un poeta do século XIX. A gran poetisa galega Rosalía de Castro. 
Esta práctica non se leva a cabo cando a forma irregular cadra xusto ao lado do lema, porque neste caso o usuario, ao buscar a forma irregular, encontra xa facilmente o lema correspondente. Isto ocorre, por exemplo, con actriz, que non figura como entrada porque caería xustamente despois de actor.

Hai un caso especial no que se lle dá cabida á forma morfoloxicamente irregular mesmo que alfabeticamente lle cadre xusto ao lado do seu lema: cando a forma do feminino ten algunha acepción distinta que non posúe a forma masculina:

\footnotetext{
duque $s . m$. (f. duquesa) Nobre do máis alto rango, despois do príncipe e inmediatamente superior ao marqués. Fomos visitar o pazo dos duques de Alba.

duquesa s.f. 1. V. duque. 2. Muller do duque. Acudiu a duquesa en representación do seu marido.
}

\subsubsection{O tratamento das locucións}

As lexías compostas e as locucións non figuran como entradas. Incorpóranse ao elemento constituínte que se considera máis importante semanticamente:

\footnotetext{
carrada s.f. 1. Carga que leva un carro dunha soa vez. Trouxeron unha carrada de toxo do monte. 2. Cada unha das viaxes que se fai cando se carrexa algo. De volta da segunda carrada foi montado no carro. 3. Gran cantidade ou gran número [de algo que se expresa]. A onde vas con esa carrada de libros? SIN. carrado, carretada. $\Delta$ A carradas. En gran abundancia. Había mazás a carradas.
}

Cando non existe un elemento semántico dominante, asígnase ao primeiro, e remítese desde o outro:

posesorio -a adx. Relativo ou pertencente á posesión. A lei esixía o transcurso dun prazo posesorio de dez. anos. $\Delta$ Xuízo posesorio. V. xuízo.

Pode darse o caso de que o elemento principal constitutivo da lexía composta ou da locución non figure como entrada do dicionario. Cando isto ocorre dáselle cabida como entrada á lexía composta ou locución. Por exemplo, a voz cabaleirola non figura como entrada do dicionario, porque non ten uso fóra da locución adverbial ás cabaleirolas, e por iso figura esta como entrada:

cabaleirolas, ás loc. adv. Escarranchado sobre os ombreiros ou o lombo. O máis pequeno levábao o pai ás cabaleirolas. SIN. a cabalo, ás cabaliñas, ao cabalete. CF. ao carrelo, ao lombo. 


\subsubsection{As palabras non normativas}

O DRAG debe ser e é un dicionario normativo, que orienta sobre o uso correcto do léxico do galego; por iso non deben figurar nel as voces non normativas. Pero debe ser tamén un dicionario didáctico, e que lle proporcione ao usuario a información que busca da maneira máis fácil posible. Esta é a razón que explica a presenza dalgunhas voces non normativas, pero que teñen certa vitalidade no uso. Dentro das voces non normativas, distínguense dous casos:

(a) O das formas das que non hai dúbida de que son galegas, pero que están marcadas cun forte carácter dialectal. Neste caso, despois da entrada, remítese para a forma máis recomendable, precedida do símbolo $\Rightarrow$ :

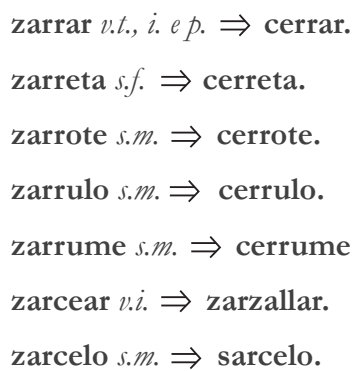

(b) O das formas que son incorrectas en galego, que van marcadas cun asterisco, e desde as cales se remite para a forma normativa galega:

\footnotetext{
*almidón s.m. amidón.
}

\section{A MICROESTRUTURA}

Que contén e como se organiza un artigo lexicográfico no DRAG? O $D R A G$ ofrece información sobre a forma gráfica do lema; información gramatical; información sobre a pronunciación (só nos casos conflitivos); información diastrática e diafásica; información tecnolectal; información sobre o carácter da acepción (fig., por ext.); a definición de cada acepción; observacións referidas á acepción; exemplos; sinónimos, antónimos e palabras próximas semanticamente; unidades pluriverbais nas que ocupa un lugar central a entrada, e observacións referidas ao enunciado. 


\subsection{O lema}

O lema é a forma non marcada: a do masculino singular, no caso dos substantivos e adxectivos; e a do infinitivo, no caso dos verbos. Encabeza sempre o artigo, e encabeza o parágrafo que contén este. Aparece sempre marcado tipograficamente dunha maneira que se faga máis visible e que destaque sobre o resto da información, para xebrar con claridade a información pertencente a un artigo da dos contiguos, e sobre todo, dado que os artigos están dispostos segundo a orde alfabética dos lemas que lle serven de entrada, para facilitarlle a busca ao usuario. No DRAG o lema aparece marcado tipograficamente en letra grosa.

\subsection{Información gramatical}

A información gramatical, deixando á parte a información implícita no sistema de definición de cada acepción, ofrécese por distintos procedementos:

(a) Un deles, sistemático, proporciona para cada lema información sobre a categoría gramatical, xénero, número, réxime verbal, etc. Esta información precede a definición de cada acepción, e vai sempre en caracteres itálicos, como se pode ver nos exemplos seguintes:

\footnotetext{
fachuzo s.m. Presa de palla atada que se acende para alumar. Levaban os fachuzos por se os collia a noite no camiño. SIN. facha ${ }^{1}$, fachico, facho, fachón, fachuco, palluzo.

azougar v.t. 1. Cubrir con azougue. Azougan o vidro pola súa cara posteriorpara convertelo en espello. // v.p. 2. Med. Contraer unha doenza caracterizada por un tremor continuo, causada pola absorción de vapores de azougue. Moitos mineiros azougábanse e morrían. 3. fig. Mostrarse moi inquieto e axitado ou estar en continuo movemento. Polas noites azougábase no leito por mor dos pesadelos.
}

(b) Información sobre a formación de femininos e plurais irregulares, que se ofrece entre parénteses, despois da categoría gramatical:

anorak $s . m$. ( $p l$. anoraks) Chaqueta impermeable con carapucha, que se usa para protexer do frío e da chuvia. Un anorak de plumas.

(c) Información gramatical complementaria, que vai introducida polo sinalizador OBS., onde poden encontrarse observacións de carácter gramatical de carácter moi variado: irregularidades na conxugación verbal, rexencias verbais, obrigatoriedade do uso do artigo, etc. 
- Información sobre as irregularidades verbais:

fuxir vi. 1. Afastarse rapidamente de algo ou alguén, polo xeral para evitar unha ameaza ou perigo. Nos tempos da guerra moitos fuxían para o monte. Os lobos foxen do lume. 2. Saír dun lugar onde se está preso por medios ilícitos. Onte á noite fuxiron varios presos. evadirse. OBS. Verbo con alternancia vocálica no pres. indic.: fuxo, foxes, foxe, fuximos, fuxides, foxen.

- Información sintagmática: obrigatoriedade de uso de artigo, rexencias verbais...:

\footnotetext{
ambos .as indef. Un e mais o outro, os dous. Hai só dúas solucións, ambas con poucas probabilidades de éxito. OBS. Cando vai modificando un substantivo, vai acompañado do artigo e pódese utilizar contraído coa segunda forma, dando como resultado as formas ámbolos e ámbalas. Ambas as partes estaban de acordo. Ámbalas partes estaban de acordo. $\Delta$ Ambos a dous. Os dous. Ambos a dous candidatos teñen as mesmas posibilidades. SIN. ambos os dous. / Ambos os dous. Ambos a dous. Ambos os dous merecian ganar.

tirar v.t. 14. Botar por terra [algo], facer caer ao chan. O temporal tirou o valado da horta. OBS. Emprégase tamén seguido da preposición con. Tirou con el do cabalo embaixo.
}

(d) Ás veces a información sintagmática sobre rexencia de certas preposicións vai indicada entre parénteses a continuación da entrada e co mesmo tipo de letra da entrada:

carecente (de) $a d x$. Que ten ou amosa algunha carencia. Carecente de estímulos e ilusións e invadida pola nostalxia decidiu regresar á súa vila natal. SIN. carecedor, carente.

\subsection{Información fonética}

No $D R A G$ non se ofrece a transcrición fonética de cada lema, pero si se proporciona información fonética sobre aqueles aspectos que poden ofrecer dificultade: a realización do timbre das vogais tónicas de grao medio $e, o$ (especialmente cando existen voces homógrafas que se distinguen unicamente polo timbre destas vogais), a pronunciación de grafemas que poden representar realidades fonolóxicas distintas, a pronunciación de estanxeirismos:

(a) Información sobre o timbre da vogal tónica cando é necesario:

pega ['peya] s.f. 1. Pau ou corda que se lles pon ás vacas, cabalos, etc. para que non fuxan cando están ceibos. Púxolle unha péga ao cabalo mentres pacía. SIN. cadarme, pexa, piega, solta, soltadoiro, traba. 2. fig. Cousa que impide o desenvolvemento normal ou a realización 
dunha acción. Non puxo ningunba péga polo cambio de día. SIN. dificultade, impedimento, inconveniente, obstáculo, pexa, traba.

(b) Pronunciación do grafema $x$ :

anorexia $[\mathrm{ks}]$ s.f. Med. Diminución ou perda do apetito. Pesa soamente trinta quilos porque sofre anorexia. CF. inapetencia. A Anorexia nerviosa. Psiq. Síndrome caracterizada pola redución voluntaria e extrema da alimentación acompañada de vómitos, que orixina adelgazamento e outras alteracións. A anorexia nerviosa é máis habitual en mulleres novas.

(c) Transcrición de estranxeirismos:

jeep [dzip] s.m.(pl. jeeps) Coche pequeno de orixe americana capaz de andar por terreos difíciles, orixinariamente utilizado polo exército. Alugamos un jeep para ir polo monte.

\subsection{Información diastrática, diafásica e diacrónica}

Dentro de calquera lingua existen variedades propias de distintos estratos sociais, de distintos rexistros, e mesmo usos que son considerados xa anticuados. Isto ocorre no plano fonético e no morfosintáctico, pero é especialmente visible no léxico. Por iso, con frecuencia, hai certas entradas ou determinadas acepcións do dicionario que van marcadas con etiquetas como: máis culto, menos culto, fam., pop, ant., etc.:

\footnotetext{
amolar v.p. 3. Sufrir molestia ou fastío. Que se amole e o faga aínda que non lle guste! SIN. amocar(se), enfastiar(se), foder(se) (vulg.).

ampola s.f. 1. Lesión cutánea producida por un levantamento da epiderme, que contén un líquido seroso. Os zapatos fixéronlle ampolas. SIN. bocha, bóchega, boza ${ }^{1}$, flictena (máis culto), vexiga, vincha, vinchoca.
}

\subsection{Información tecnolectal}

Tamén se ofrece información tecnolectal, na que se indica a lingua de especialidade á que pertence unha determinada voz ou unha acepción concreta desa voz. Esta información transmítese por medio de etiquetas, tales como Zool., Bot., Biol...., que van situadas en letra itálica inmediatamente antes da definición da acepción.

ampere s.m. Fís. Unidade de intensidade de corrente eléctrica do sistema internacional. O seu símbolo é $A$. $\Leftarrow$ amperio. Un limitador de 15 amperes.

anacruse s.f. 1. Lit. Na métrica clásica, sílaba que está diante da que inicia o primeiro pé completo. Na métrica grecolatina considérase que a sílaba en anacruse non forma parte do metro. 2 . Lit. Na métrica mo- 
derna, sílaba ou sílabas átonas que preceden o primeiro acento dun verso. Un verso con dúas sílabas en anacruse. 3. Mús. Nota ou grupo de notas dunha melodía que preceden o primeiro tempo forte. Unba melodía que comeza en anacruse.

\title{
5.6. Información sobre a natureza da acepción (ext., fig.)
}

\begin{abstract}
anaerobio -a $a d x$. 1. Biol. [Organismo] que é capaz de vivir sen a presenza de osíxeno no aire. Bacteria anaerobia. 2. Propio dos microorganismos anaerobios. Respiración anaerobia. 3. ext. [Motor, propulsor] que pode funcionar sen aire. Os propulsores anaerobios funcionan fóra da atmosfera. // s.m. 4. Biol. Microorganismo anaerobio. Unha infección producida por anaerobios. O xerme que produce o botulismo é un anaerobio. ANT. aerobio.
\end{abstract}

\begin{abstract}
anatematizar v.t. 1. Pronunciar ou lanzar un anatema unha autoridade eclesiástica contra [alguén]. Anatematizárono por herexe. CF. excomungar. 2. fig. Reprobar enerxicamente ou condenar moralmente. Anatematizou a súa ideoloxía e comportamento.

carburar vi. 3. fig. e pop. Funcionar. A televisión non carbura, non sei qué lle pasa. 4. fig. e pop. Razoar. Ti non carburas.
\end{abstract}

\subsection{A definición}

\subsubsection{Que é a definición?}

A definición consiste en facer corresponder unha unidade léxica, descoñecida ou mal coñecida, cunha serie de unidades pertencentes ao mesmo sistema lingüístico, organizadas segundo as estruturas sintagmáticas deste sistema, e que sexa capaz de remitir ao mesmo significado e de determinar no usuario do dicionario a elaboración conceptual deste significado.

\subsubsection{Definicións propias / definicións impropias}

É xa clásica a distinción entre definicións propias e definicións impropias, aínda que en realidade estas últimas non son verdadeiras definicións.

As definicións impropias están formuladas en metalingua de signo, e non se deixan someter á "lei da sinonimia". Non son verdadeiras definicións ("qué significa a palabra"), senón explicacións ("cómo e para qué se emprega a palabra"). As palabras ás que se aplica este tipo de definición -interxeccións e palabras gramaticais (preposicións, conxuncións, pronomes, artigos e certos adverbios, adxectivos e verbos)- son realmente indefinibles: 
lle, lles pron. pers. Formas átonas de terceira persoa singular e plural respectivamente, en función de complemento indirecto. Fixenlles pedir perdón. Non lles soubo contestar. OBS. lle e lles contraen cos pronomes persoais o, a, os, as e lo, la, los, las dando lugar ás formas Ilo, lla, llos, llas e llelo, llela, llelos, llelas, respectivamente.

As definicións propias son as verdadeiras definicións lexicográficas, están formuladas en metalingua de contido e nelas rexe o principio de substituibilidade entre definido e definidor (son as definicións que corresponden a todos os nomes e á inmensa maioría dos adxectivos, verbos e adverbios).

A lexicóloga e lexicógrafa J. Rey-Debove (1967), nunha das clasificacións máis aceptadas das definicións propias, distingue entre definición substancial e definición relacional. Na definición substancial a análise sémica incide na substancia do definido. A definición relacional incide na relación do definido con outra palabra do enunciado.

\subsection{A definición substancial}

Hai un caso, que podemos considerar "atípico", de definición substancial: é o dos enunciados definitorios ordinarios, sistema seguido por exemplo no Cobuild. É un tipo especial de definición que, baseándose en situacións comunicativas, exhibe unha serie de notas que permiten ao usuario do dicionario identificar a palabra cun significado determinado. Serían definicións do tipo:

\footnotetext{
chover: cando cae auga e imos co paraugas aberto, dicimos que chove.

preservar: se preservas algunha cousa, tomas medidas para conservala ou protexela para que non se estrague, non se perda ou non a rouben.
}

Este tipo de información é útil cando se trata de palabras referidas á esfera da vida da que o usuario ten experiencia, pero resulta pouco práctica ou inservible cando se refire a conceptos sobre os que o usuario non ten experiencia.

No DRAG seguimos outro tipo de definición substancial, máis coñecido e máis utilizado na tradición lexicográfica, que se basea na análise tradicional aristotélica do concepto do definido polo "xénero próximo" e a "diferenza específica". O xénero próximo denomínase incluínte. Corresponde co que Ignacio Bosque (1982) denomina "definición hiperonímica".

A definición substancial é unha resposta directa á pregunta: Que é o definido? Esta resposta preséntase conceptualmente baixo tres formas: 

(a) o definido é tal cousa
(b) o definido é non tal cousa
(c) o definido é o contrario ou a ausencia de tal cousa.

As tres formas de definición conceptual aparecen no noso dicionario. Por iso, aínda que sexa brevemente, imos ver algunha das características da inclusión, da exclusión e da inclusión negativa.

\section{a) A inclusión}

O incluínte é a expresión do concepto clasificador, e pertence á mesma categoría gramatical ca o definido. Semanticamente, todo o semema do incluínte está contido no definido, como por exemplo cabaleiro = 'home a cabalo'.

A maioría das definicións do DRAG presentan unha relación de inclusión:

\footnotetext{
$1 \mathbf{a}^{2}$ s.f. 1. Pelo da ovella ou do carneiro. Raparlles a la ás ovellas. 2. ext. Pelo dalgún outro animal, semellante á la. A la dos camelos. 3. Fío de la. Mercamos unhas madeixas de la para facerlle unha mantiña ao bebé. 4. Tecido de la. Un xersei de la. Un colchón de la. Un abrigo de la. $\Delta$ Baraza de la. V. baraza.
}

lacar v.t. Cubrir con laca [un moble ou outro obxecto]. Ela mesma lacou os mobles do salón.

b) A exclusión

O procedemento da exclusión consiste en definir unha palabra negando o seu oposto (por exemplo, abandonar = 'non continuar'). Neste caso non se trata dun estudo interno do semema do definido, senón dun estudo externo que supón a existencia e o coñecemento de parellas de contrarios. Isto é o que atopamos en definicións como as seguintes:

\footnotetext{
abandonar v.t. 3. Non continuar con [algo]. Abandonaron os seus plans de ataque. Os guerrilleiros abandonaron a loita. // v.p. 4 . Non coidar de si. Dun tempo para acá abandonouse de tal xeito que parece un farrapeiro. SIN. desleixarse.

lizquente $a d x$. Nin frío nin quente. Non me gusta o leite lizquente, quéroo fervendo. SIN. morno, temperado, tépedo.

amuar vi.i. 4. Non responder ao que preguntan, baixando a cabeza. Por máis que lle preguntaban, non conseguian nada, ela amuaba.
}

c) A inclusión negativa

Neste tipo de definición existe un incluínte que serve para negar o excluínte. Trátase, pois, dunha negación semántica, non dunha negación sintáctica. É o que aparece en: 
impericia s.f. Falta de pericia. A impericia da tripulación provocou o afundimento do barco. ANT. destreza, pericia. CF. inhabilidade.

avitaminose s.f. Med. Carencia ou deficiencia de vitaminas, que pode causar enfermidades. O escorbuto é unha das numerosas enfermidades provocadas por avitaminose.

\subsection{A definición relacional}

A definición relacional non envía só á substancia do definido, senón á relación entre o definido cualificador e outra palabra cualificada. Só concerne ao adxectivo e ao adverbio.

Para o adxectivo esta relación exprésase:

(a) por un relativo:

anoxadizo -a $a d x$. Que se anoxa facilmente. Éche moi anoxadizo pero axiña lle pasa. SIN. asañadizo.

(b) ou por unha preposición:

anfractuoso -a $a d x$. Con moitas irregularidades. Relevo anfractuoso.

Para o adverbio exprésase sempre por unha preposición:

atentamente $a d v$. 1. Con atención ou cortesía. Observaba atentamente os costumes dos habitantes da zona.

5.7.1.2. O principio de substituibilidade e a separación do núcleo e o contorno

Nas definicións do DRAG procurouse aplicar o principio de substituibilidade. Se o enunciado definidor pode substituír o termo definido nun enunciado de fala sen que se altere o sentido obxectivo deste, o enunciado definidor será válido. Isto implica que entre definido e definiente debe existir unha identidade categorial.

O principio de substituibilidade obrigou á separación do núcleo da definición do seu contorno. O contorno vai marcado entre corchetes, tal como pode verse nos seguintes artigos do DRAG:

anaerobio -a $a d x$. 1. Biol. [Organismo] que é capaz de vivir sen a presenza de osíxeno no aire. Bacteria anaerobia. 2. Propio dos microorganismos anaerobios. Respiración anaerobia. 3. ext. [Motor, 
propulsor] que pode funcionar sen aire. Os propulsores anaerobios funcionan fóra da atmosfera. ANT. aerobio.

ampolar v.t. 1. Producir unha ou máis ampolas en [unha parte do corpo]. Os zapatos novos ampoláronlle os pés. // v.p. 2. [Parte do corpo] sufrir a formación dunha ou máis ampolas. Ampoláronseme as mans de tanto traballar.

anatematizar v.t. 1. Pronunciar ou lanzar un anatema unha autoridade eclesiástica contra [alguén]. Anatematizárono por herexe. CF. excomungar. 2. fig. Reprobar enerxicamente ou condenar moralmente. Anatematizou a súa ideoloxía e comportamento.

\subsection{A ordenación das acepcións}

Existen tres criterios principais de ordenación das acepcións:

(a) lóxico: unha acepción debe anteceder a outra que deriva dela;

(b) histórico: a orde das acepcións segue a orde de documentación histórica;

(c) frecuencia: as acepcións deben ordenarse por frecuencia de uso.

No DRAG procurouse combinar a frecuencia de uso coa ordenación lóxica, pero estes criterios sempre se subordinan á clasificación por categoría gramatical, tal como se pode observar nos seguintes exemplos:

\footnotetext{
amarelo -a $a d x$. 1. Que ten a cor entre verde e laranxa, coma a do ouro, o limón maduro, etc. Mercou unha camisa amarela. Aos actores supersticiosos non lles gusta a cor amarela. 2. [persoa] Falto de cor. Atopeino amarelo, apoucado, fraco..., debe estar enfermo. SIN. esbrancuxado, pálido. // s.m. 3. A cor amarela. Pintaron o cuarto de amarelo. $\Delta$ Febre amarela. V. febre. / Raza amarela. V. raza. SIN. marelo.

amolar v.t. 1. Causar molestia ou fastío. Amólame ter que levantarme todos os días ás sete. SIN. amargar, molestar. Que perdeu o Celta, dis?, non me amoles! 2. Facer fío a [unha ferramenta]. Amolou os fouciños na moa. SIN. afiar, aguzar. // v.p. 3. Sufrir molestia ou fastío. Que se amole e o faga aínda que non lle guste! SIN. amocar(se), enfastiar(se), foder(se) (vulg.).
}

\subsection{Os exemplos}

Todas as acepcións levan un ou varios exemplos, que contribúan a:

(a) aclarar máis o significado, ofrecendo trazos do significado que non son substanciais, pero si habituais; 
(b) ilustrar sobre o uso;

(c) ver o comportamento sintagmático, e ofrecer as colocacións máis frecuentes;

(d) dar a coñecer aspectos da cultura propia, tal como se pode observar por exemplo en:

trasgar v.t. Colocarlle a trasga a [un animal]. Antes de muxir a vaca trásgaa para que non te manque.

noitevella s.f. Noite do trinta e un de decembro ao un de xaneiro. En noitevella moita xente sae despois de cear para celebrar a entrada do ano novo. SIN. fin de ano.

\subsection{A rede de relacións léxicas}

Cada acepción vai seguida dos sinónimos, antónimos e voces de sentido próximo, por esta orde. Os sinónimos van precedidos polo marcador SIN., os antónimos por ANT., e as voces de sentido próximo por CF.

\footnotetext{
atoar v.t. 1. Cerrar [un conduto] nalgún punto e impedir ou dificultar o paso dun fluído. O po atoon o tubo do gas. SIN. atascar, atrancar, obstruír, trancar. ANT. desatascar, desatoar. CF. cangar, tapar. 2. Cubrir de terra ou doutra cousa semellante. Atoou as brasas para que non prendesen lume. // v.p. 3. [Un conduto] quedar parcial ou totalmente cerrado por acumularse unha materia no seu interior. Atoouse a canle da anga. SIN. atascarse, atrancarse, obstruírse, trancarse. ANT. desatascarse, desatoarse, desatrancarse. 4. Quedar cuberto de terra ou doutra cousa semellante. Atoouse ata os xeonllos na neve. SIN. atuír(se). ANT. desatuír(se).
}

Como pode observarse tamén no exemplo anterior, cando un sinónimo ou antónimo o é de todas as acepcións, vai ao final de todo, precedido do símbolo

\subsection{As unidades pluriverbais}

As unidades pluriverbais (locucións e todo tipo de fraseoloxismos) van ao final do artigo, despois das acepcións, ordenadas alfabeticamente, co significado e exemplo. Van precedidas do símbolo $\boldsymbol{\Delta}$ :

pau s.m. 1. Calquera anaco de madeira longo e delgado. Cun pau e unha xesta fixo unha vasoira. Pau da luг: Pau do teléfono. 2. Mar. Poste de madeira ou de ferro, colocado en posición vertical nun barco, que sostén as velas e, nas embarcacións modernas, as antenas de radio, os focos, etc. O forte vento rompen 0 pan do veleiro. SIN. mastro. 3. Materia compacta e dura que está debaixo da casca das árbores e doutras plantas. Uns zocos con sola de pau. SIN. madeira ${ }^{1}$. 4. Cada unha das series de naipes que ten a baralla. Os paus da baralla son: ouros, copas, espadas e bastos. 5. Dep. Instrumento con que se golpea a pelota en determinados deportes, como o golf, o béisbol, etc. Xogaba ao golf cuns paus de seu avó. 6. Golpe dado cun pau ou con outro obxecto semellante. Como non cales, vas levar un pau. Ti o que estás buscando son uns 


\begin{abstract}
paus. 7. col. Desgraza ou suceso adverso. Para a familia foi un pau que a filla tivese que abandonar o país. 8. Trazo vertical ou case vertical, na escritura. Comezan por facer uns paus. O pau do 'd'. 9. Heráld. Peza que se coloca verticalmente na metade do escudo e que, cando é unha soa, ocupa a terceira parte deste. Destacaba a cor vermella do pau do escudo. $\mathbf{A}$ A darlle cun pau. En abundancia. Había peixe a darlle cun pau. / A paus. De maneira violenta. Remataron a discusión a paus. / Arado de pau. V. arado. / Culler de pau. V. culler. / Dar paus de cego. Facer algo de maneira irreflexiva e sen saber se se vai obter algún resultado. Vai pola vida dando paus de cego. / Pata de pau. V. pata. / Pau brasil. V. brasil ${ }^{2}$. / Pau de ferro. Pauferro. Fixeron un buraco na terra co pau de ferro para chantar as estacas. / Pau de San Gregorio. Arbusto ou árbore de pequeno tamaño da familia das rosáceas (Prunus padus), de tronco delgado, follas ovais, oblongas e lixeiramente dentadas, flores brancas moi aromáticas reunidas en acios e froito en drupa. O pau de San Gregorio cultivase como planta ornamental. / Pau maior. Mar. Pau máis alto dunha embarcación e que sostén a vela principal. O pau maior é paralelo ao trinquete. / Peixe pau. V. peixe. / Teso coma un pau. Cheo de arrogancia. Nin mirou para min, ía teso coma un pau.
\end{abstract}

\title{
6. RESPECTO AOS DEREITOS
}

Hai un aspecto non suficientemente traballado nos dicionarios, e particularmente nos dicionarios de institucións que teñen entre os seus cometidos o de orientar sobre o uso correcto do idioma, ou que posúen un forte ascendente social por gozaren dun alto prestixio. En todos os dicionarios, pero especialmente nos destas institucións, ha de procurarse non dar cabida ás definicións lexicográficas subxectivas, fomentar o respecto polos dereitos humanos, respectar escrupulosamente todos os pobos e culturas, e eliminar os elementos que impliquen manifestación sexista, directa ou indirecta. Nós procuramos camiñar por este sendeiro, aínda recoñecendo que é necesario seguir traballando para conseguir que o dicionario non só sexa un modelo de corrección lingüística, senón tamén, na medida do posible, de corrección social, e que os principios democráticos de respecto a todas as culturas e de igualdade entre todas as persoas se vexan plasmados nidiamente no contido da obra.

7. TIPOGRAFÍA, CONVENCIÓNS, SÍMBOLOS, ABREVIATURAS, ETC.

\subsection{A tipografía}

O coñecemento da tipografía e convencións son fundamentais para manexar o dicionario. A tipografía e as convencións son elementos significativos importantes que forman parte da metalingua das obras lexicográficas.

Respecto aos tipos de letra, a estrutura do dicionario é totalmente ríxida: a entrada vai sempre en letra grosa dun corpo lixeiramente maior ca 
o resto da información incluída no artigo lexicográfico, a categoría en cursiva, a definición da acepción en redonda, os exemplos en cursiva, as locucións e fraseoloxismos en grosa; os sinónimos, antónimos e voces relacionadas, en grosa itálica; e as observacións van cunha letra de corpo máis pequeno.

\subsection{Símbolos e marcas tipográficas}

// separa acepcións en que a entrada ten distinta categoría gramatical ou distinto xénero ou número;

I separa as locucións, frases feitas, expresións, sintagmas, etc.;

$\Rightarrow \quad$ marca que a palabra que vén a continuación se prefire á da entrada, sen ser esta incorrecta;

$\Leftarrow \quad$ marca que a palabra que vén a continuación é un sinónimo ou unha variante da entrada, que non se recomenda pero que se acepta;

* marca as formas que se consideran incorrectas;

- indica que a información que se ofrece a continuación é válida para todas as acepcións da entrada;

- introduce as locucións, frases feitas, expresións, etc.;

[ ] marcan o contorno da definición e a información fonética do lema;

() marcan rexencia de preposición, nome científico de animais e plantas, elementos opcionais da fraseoloxía;

1,2,3... empréganse para diferenciar as entradas nas palabras homógrafas;

1,2,3... empréganse para separar acepcións.

\subsection{Abreviaturas}

Non é necesario insistir na importancia que nunha obra como un dicionario ten a economía de espazo. Por iso, en poucas obras se fai un uso tan profuso das abreviaturas. A maioría delas están destinadas a facilitar información sobre o uso, información gramatical, información tecnolectal e información sobre as redes léxicas. Velaquí as máis utilizadas no $D R A G$ para cada un destes grupos. 
7.3.1. Información de uso (diafásica, diastrática, diacrónica)

$\begin{array}{ll}\text { ant. } & \text { anticuado ou antigo } \\ \text { col. } & \text { coloquial } \\ \text { desus. } & \text { desusado } \\ \text { fam. } & \text { familiar } \\ \text { lit. } & \text { literario } \\ \text { pex. } & \text { pexorativo } \\ \text { pop. } & \text { popular } \\ \text { prop. } & \text { propio } \\ \text { vulg. } & \text { vulgar }\end{array}$

7.3.2. Información gramatical

$\begin{array}{ll}\text { abs. } & \text { absoluto (verbo) } \\ \text { adv. } & \text { adverbio } \\ \text { adx. } & \text { adxectivo } \\ \text { art. } & \text { artigo } \\ \text { art. det. } & \text { artigo determinado } \\ \text { art. indet. } & \text { artigo indeterminado } \\ \text { contr. } & \text { contracción } \\ \text { conx. } & \text { conxunción } \\ \text { dem. } & \text { demostrativo } \\ \text { exclam. } & \text { exclamativo } \\ \text { f. } & \text { feminino } \\ \text { fut. } & \text { futuro } \\ \text { fut. pret. } & \text { futuro do pretérito } \\ \text { i. } & \text { intransitivo } \\ \text { imperat. } & \text { imperativo } \\ \text { imperf. } & \text { imperfecto } \\ \text { indef. } & \text { indefinido } \\ \text { indic. } & \text { indicativo } \\ \text { inf. } & \text { infinitivo } \\ \text { inf. conxug. } & \text { infinitivo conxugado } \\ \text { interrog. } & \text { interrogativo } \\ \text { interx. } & \text { interxección } \\ \text { irreg. } & \text { irregular } \\ \text { loc. } & \text { locución } \\ \text { loc. adv. } & \text { locución adverbial } \\ \text { loc. adx. } & \text { locución adxectiva }\end{array}$




\begin{tabular}{|c|c|}
\hline loc. $\operatorname{con} x$. & locución conxuntiva \\
\hline loc. lat. & locución latina \\
\hline loc. prep. & locución preposicional \\
\hline loc.s. & locución substantiva \\
\hline loc. s. lat. & locución substantiva latina \\
\hline$m$. & masculino \\
\hline$n$. & neutro \\
\hline num. & numeral \\
\hline num. card. & numeral cardinal \\
\hline num. ord. & numeral ordinal \\
\hline$p$ & pronominal \\
\hline part. & participio \\
\hline perf. & perfecto \\
\hline pl. & plural \\
\hline plusc. & pluscuamperfecto \\
\hline pos. & posesivo \\
\hline pref. & prefixo \\
\hline prep. & preposición \\
\hline pres. & presente \\
\hline pret. & pretérito \\
\hline pron. & pronome \\
\hline pron. pers. & pronome persoal \\
\hline rel. & relativo \\
\hline s. & substantivo \\
\hline sing. & singular \\
\hline subx. & subxuntivo \\
\hline t. & transitivo \\
\hline$v$. & verbo \\
\hline xer. & xerundio \\
\hline
\end{tabular}

\subsubsection{Tecnolectos}

$\begin{array}{ll}\text { Aeron. } & \text { Aeronáutica } \\ \text { Agr. } & \text { Agricultura } \\ \text { Anat. } & \text { Anatomía } \\ \text { Antig. } & \text { Antigüidade clásica } \\ \text { Antrop. } & \text { Antropoloxía } \\ \text { Arqueol. } & \text { Arqueoloxía } \\ \text { Arquit. } & \text { Arquitectura } \\ \text { Art. } & \text { Arte }\end{array}$




\begin{tabular}{|c|c|}
\hline Astrol. & Astroloxía \\
\hline Astron. & Astronomía \\
\hline Bibliol. & Bliblioloxía \\
\hline Biol. & Bioloxía \\
\hline Bioquím. & Bioquímica \\
\hline Bot. & Botánica \\
\hline Catol. & Catolicismo \\
\hline Cinem. & Cinematografía \\
\hline Cir. & Cirurxía \\
\hline Dep. & Deportes \\
\hline Der. & Dereito \\
\hline Econ. & Economía \\
\hline Electr. & Electricidade \\
\hline Electrón. & Electrónica \\
\hline Enxeñ. & Enxeñería \\
\hline Farm. & Farmacia \\
\hline Filos. & Filosofía \\
\hline Fís. & Física \\
\hline Fon. & Fonética e Fonoloxía \\
\hline Fot. & Fotografía \\
\hline Gram. & Gramática \\
\hline Heráld. & Heráldica \\
\hline Hist. & Historia \\
\hline Impr. & Imprenta \\
\hline Inform. & Informática \\
\hline Ling. & Lingüística \\
\hline Lit. & Literatura \\
\hline Mar. & Marítimo \\
\hline Mat. & Matemáticas \\
\hline Mec. & Mecánica \\
\hline Med. & Medicina \\
\hline Metal. & Metalurxia \\
\hline Meteor. & Meteoroloxía \\
\hline Métr. & Métrica \\
\hline Micol. & Micoloxía \\
\hline Mil. & Milicia \\
\hline Miner. & Mineraloxía \\
\hline Mit. & Mitoloxía \\
\hline Mús. & Música \\
\hline Ópt. & Óptica \\
\hline
\end{tabular}




$\begin{array}{ll}\text { Paleogr. } & \text { Paleografía } \\ \text { Petrogr. } & \text { Petrografía } \\ \text { Pint. } & \text { Pintura } \\ \text { Pol. } & \text { Política } \\ \text { Psic. } & \text { Psicoloxía } \\ \text { Psiq. } & \text { Psiquiatría } \\ \text { Quím. } & \text { Ouímica } \\ \text { Radiod. } & \text { Radiodifusión } \\ \text { Relix. } & \text { Relixión } \\ \text { Ret. } & \text { Retórica } \\ \text { Silv. } & \text { Silvicultura } \\ \text { Sociol. } & \text { Socioloxía } \\ \text { Taurom. } & \text { Tauromaquia } \\ \text { Telecom. } & \text { Telecomunicacións } \\ \text { Teol. } & \text { Teoloxía } \\ \text { Tip. } & \text { Tipografía } \\ \text { Top. } & \text { Topografía } \\ \text { Vet. } & \text { Veterinaria } \\ \text { Xenét. } & \text { Xenética } \\ \text { Xeogr. } & \text { Xeografía } \\ \text { Xeol. } & \text { Xeoloxía } \\ \text { Xeom. } & \text { Xeometría } \\ \text { Zool. } & \text { Zooloxía } \\ & \end{array}$

7.3.4. Rede léxica
ANT.
antónimo
CF.
compárese
SIN.
sinónimo

\subsubsection{Outras}

ac.

a. C.

d. C.

ex.

ext.

obs.

séc.

V. acepción

antes de Cristo

despois de Cristo

exemplo

extensión

observación

século

véxase 